\title{
THE ESTIMATION OF SERUM SODIUM FROM BICARBONATE PLUS CHLORIDE ${ }^{1}$
}

\author{
By P. M. HALD, A. J. HEINSEN, AND J. P. PETERS \\ (From the Department of Internal Medicine, Yale University School of Medicine, New Haven)
}

(Received for publication March 5, 1947)

Since the body fluids are nearly neutral and since they contain no appreciable quantities of organic bases, the concentration of cations in these fluids must be equal to the concentration of the inorganic cations found in them, $[\mathrm{Na}]+[\mathrm{K}]+$ $[\mathrm{Ca}]+[\mathrm{Mg}]$. This, in turn, must be equal to the total concentration of anions. The distribution of water between cells and extracellular fluids in the body appears to be governed mainly by the concentration in the extracellular fluids of sodium, the principal one of those osmotically active components which are restrained from crossing the cellular membranes. In addition, sodium constitutes the chief cation of the extracellular fluids. In normal serum it makes up more than 90 per cent of the total concentration of cations. Although the concentrations of the other cations profoundly influence physiological processes, they are so small and vary so little that their effects on osmotic and cation-anion equilibria are trifling. The concentration of sodium is, therefore, the best single criterion of the electrolyte osmotic pressure and the concentration of cations in the serum and extracellular fluids. The measurement of sodium has, however, been so laborious and time-consuming that it has been less useful for clinical than for investigative purposes.

In lieu of direct measurement the concentration of sodium has usually been estimated from the combined concentrations of bicarbonate and chloride. In normal subjects these 2 ions together make up from 85 to 90 per cent of the anions of serum, falling only a little short of equaling sodium. The remainder of the anion column is composed chiefly of protein, with an inconsiderable amount of inorganic phosphate, an almost negligible quantity of sulfate and a small and variable contribution of organic acids. While important variations of the concentrations of cations manifest themselves

1 This investigation was aided by a grant from the Fluid Research Funds of the Yale University School of Medicine. consistently in the concentration of sodium, variations of the anions are not so consistently evidenced in the concentrations of $\mathrm{HCO}_{3}+\mathrm{Cl}$. If some other foreign or endogenous anion accumulates in the serum it will displace bicarbonate. In this case $[\mathrm{Na}]$ will exceed $\left[\mathrm{HCO}_{3}\right]+[\mathrm{Cl}]$ by more than the usual quantity and can be estimated only by the aid of inference.

The object of this paper is to examine the accuracy of such inferences. With the flame photometer it will become possible to measure the sodium of serum with sufficient speed and facility to make this measurement clinically available. It is therefore relevant to ascertain the indications for such measurements and the advantages and disadvantages they have in comparison with measurements of $\left[\mathrm{HCO}_{3}\right]+[\mathrm{Cl}]$ and other combinations of procedures. For routine purposes some selection is desirable for economy of time, facilities, and blood.

\section{MATERIAL}

The material on which this analysis is based consists of 205 measurements of sodium, chloride, and $\mathrm{CO}_{2}$ of serum from 28 normal adults and 63 patients with a variety of diseases, made for various reasons during the years 1932 to 1947. In many instances other analyses were made. The subjects for clinical observation were not selected at random, but usually because some abnormality of sodium or of the relation between sodium and chloride + bicarbonate was suspected.

All normals and most patients were studied in the postabsorptive state before breakfast. Exceptions to this rule were made in emergencies; but in such instances the patients were almost invariably fasting.

\section{METHODS}

Blood was drawn and serum was separated and preserved with anaerobic precautions. Chloride was measured by Eisenman's adaptation of the method of Austin and Van Slyke (1) or by Hald's modification of Patterson's micromethod (1) ; carbon dioxide was measured by the technique of Van Slyke and Neill (1), with the constant volume apparatus. Analyses for sodium were done by the gravimetric method of Hald (2) or by means of the flame photometer (3), or both. 


\section{CALCULATIONS}

Values for sodium, chloride, bicarbonate and other electrolytic components are given in terms of combining equivalents. Actually the figures for bicarbonate do not represent bicarbonate, since the $\mathrm{CO}_{2}$ tension of the blood was not determined. They represent total $\mathrm{CO}_{2}$ minus the $\mathrm{CO}$, that would be held in solution and as $\mathrm{H}_{3} \mathrm{CO}_{3}$ in the serum at $37.5^{\circ} \mathrm{C}$. and a $\mathrm{pH}$ of 7.35.2 Since the clinical

${ }^{2}$ For this calculation the value of 6.10 was used for $\mathrm{pK}_{1}^{\prime} ;(4)$.

TABLE I

Variations of serum electrolyte concentrations in health and disease

\begin{tabular}{|c|c|c|c|c|c|c|c|c|}
\hline \multicolumn{2}{|c|}{ Number of } & \multirow{2}{*}{ [HCO $]$} & \multirow{2}{*}{ [Cl] } & \multirow{2}{*}{$\Sigma$} & \multirow{2}{*}{ [Na] } & \multicolumn{3}{|c|}{$\Delta$} \\
\hline \multirow[t]{2}{*}{ _ Subjects } & $\begin{array}{c}\text { Observa- } \\
\text { tions }\end{array}$ & & & & & Observed & $>11$ & $>16$ \\
\hline & & \multicolumn{7}{|c|}{ meq. per liter } \\
\hline
\end{tabular}

Normal males*

\begin{tabular}{|c|c|c|c|c|c|c|c|c|c|}
\hline 16 & 19 & $\begin{array}{l}\text { Maximum } \\
\text { Minimum } \\
\text { Mean. } \\
\text { s.d. } \pm\end{array}$ & $\begin{array}{c}30.5 \\
25.7 \\
27.7 \\
1.34\end{array}$ & $\begin{array}{c}104.4 \\
100.0 \\
102.7 \\
1.13\end{array}$ & $\begin{array}{c}132.7 \\
128.3 \\
130.2 \\
1.58\end{array}$ & $\begin{array}{r}143.3 \\
132.4 \\
135.7 \\
2.28\end{array}$ & $\begin{array}{l}10.9 \\
2.8 \\
5.8 \\
2.26\end{array}$ & & \\
\hline \multicolumn{10}{|c|}{ Normal females $t$} \\
\hline 12 & 16 & $\begin{array}{l}\text { Maximum } \\
\text { Minimum } \\
\text { Mean } \\
\text { s.d. } \pm\end{array}$ & $\begin{array}{c}28.1 \\
23.1 \\
25.2 \\
1.42\end{array}$ & $\begin{array}{c}106.8 \\
103.2 \\
105.3 \\
0.92\end{array}$ & $\begin{array}{c}133.2 \\
128.0 \\
130.5 \\
1.06\end{array}$ & $\begin{array}{c}136.7 \\
129.0 \\
133.4 \\
3.11\end{array}$ & $\begin{array}{c}8.4 \\
-1.3 \\
4.0 \\
2.33\end{array}$ & & \\
\hline \multicolumn{10}{|c|}{ Addison's disease } \\
\hline 5 & 37 & $\begin{array}{l}\text { Maximum } \\
\text { Minimum }\end{array}$ & $\begin{array}{l}27.5 \\
14.8\end{array}$ & $\begin{array}{r}107.1 \\
82.6\end{array}$ & $\begin{array}{l}131.5 \\
102.6\end{array}$ & $\begin{array}{l}141.0 \\
115.9\end{array}$ & $\begin{array}{r}18.2 \\
2.8\end{array}$ & 9 & 1 \\
\hline \multicolumn{10}{|c|}{ Pulmonary disease } \\
\hline 6 & 18 & $\begin{array}{l}\text { Maximum } \\
\text { Minimum }\end{array}$ & $\begin{array}{l}56.0 \\
19.8\end{array}$ & $\begin{array}{r}105.3 \\
75.1\end{array}$ & $\begin{array}{l}131.1 \\
112.4\end{array}$ & $\begin{array}{l}146.0 \\
122.8\end{array}$ & $\begin{array}{r}20.1 \\
5.7\end{array}$ & 4 & 2 \\
\hline \multicolumn{10}{|c|}{ Diabetes mellitus } \\
\hline 18 & 45 & $\begin{array}{l}\text { Maximum } \\
\text { Minimum }\end{array}$ & $\begin{array}{r}31.0 \\
3.6\end{array}$ & $\begin{array}{r}122.4 \\
87.1\end{array}$ & $\begin{array}{r}135.8 \\
99.3\end{array}$ & $\begin{array}{l}151.6 \\
119.5\end{array}$ & $\begin{array}{r}45.5 \\
1.8\end{array}$ & 34 & 21 \\
\hline \multicolumn{10}{|c|}{ Renal disease } \\
\hline 13 & 23 & $\begin{array}{l}\text { Maximum } \\
\text { Minimum }\end{array}$ & $\begin{array}{r}28.1 \\
4.9\end{array}$ & $\begin{array}{r}125.5 \\
81.3\end{array}$ & $\begin{array}{r}132.2 \\
97.5\end{array}$ & $\begin{array}{l}148.5 \\
116.2\end{array}$ & $\begin{array}{r}34.7 \\
0.7\end{array}$ & 16 & 12 \\
\hline \multicolumn{10}{|c|}{ Mercury poisoning } \\
\hline 4 & 18 & $\begin{array}{l}\text { Maximum } \\
\text { Minimum }\end{array}$ & $\begin{array}{r}24.3 \\
9.5\end{array}$ & $\begin{array}{r}131.8 \\
86.7\end{array}$ & $\begin{array}{l}152.4 \\
100.0\end{array}$ & $\begin{array}{l}167.6 \\
117.3\end{array}$ & $\begin{array}{r}23.4 \\
0.0\end{array}$ & 14 & 2 \\
\hline \multicolumn{10}{|c|}{ Miscellaneous diseases } \\
\hline 17 & 29 & $\begin{array}{l}\text { Maximum } \\
\text { Minimum }\end{array}$ & $\begin{array}{r}40.9 \\
9.7\end{array}$ & $\begin{array}{r}103.5 \\
67.8\end{array}$ & $\begin{array}{r}130.0 \\
91.6\end{array}$ & $\begin{array}{l}141.0 \\
116.0\end{array}$ & $\begin{array}{r}27.3 \\
0.1\end{array}$ & 20 & 10 \\
\hline
\end{tabular}

* One subject was omitted because his $[\mathrm{Na}]$ and $\Delta$ differed consistently from the mean by more than 3 times the standard deviation.

t One subject was omitted because her $[\mathrm{Cl}]$ and $\Sigma$ differed consistently from the mean by more than 3 times the standard deviation. 
material was extremely heterogeneous $\mathrm{pH}$ must have varied widely. If it be assumed that it varied from $\mathbf{7 . 0}$ to 7.8 , the error of assuming a $\mathrm{pH}$ of 7.35 would amount to \pm 7 per cent of the bicarbonate value. In a serum with a normal bicarbonate concentration of 27 milliequivalents per liter this would be about 2 milliequivalents.

In the text and tables concentrations of $\mathrm{Na}, \mathrm{Cl}$ and $\mathrm{HCO}_{3}$, in meq. per liter, are represented with brackets, $[\mathrm{Na}],[\mathrm{Cl}],\left[\mathrm{HCO}_{3}\right]$. The sum, $\left[\mathrm{HCO}_{3}\right]+[\mathrm{Cl}]$, is represented by the symbol $\Sigma$, the difference, $[\mathrm{Na}]-\left(\left[\mathrm{HCO}_{8}\right]\right.$ $+[\mathrm{Cl}])$, by the Symbol $\Delta$.

\section{RESULTS}

In Table I the data are presented in summary to indicate the degree of variability of each function in normal individuals and in various types of disease. There is, as has been noted before $(4,5)$, a statistically significant difference between normal males and females with respect to both $\left[\mathrm{HCO}_{3}\right]$ and $[\mathrm{Cl}]$. The former is about 2.5 meq. per liter lower, while $[\mathrm{Cl}]$ is about 2.5 meq. higher in females. Because these differences are reciprocally related, $\Sigma$ is the same for the 2 sexes. In this series the mean [ $\mathrm{Na}$ ] is 2.5 meq. higher in males, but this is not statistically significant. One male and one female, though presumably normal, were omitted from the statistical calculations because their electrolytes departed in certain particulars widely from the means. If they had been included the means would have been only slightly altered, while the differences between the sexes would have been exaggerated. In each sex $[\mathrm{Cl}]$ varies less than any other function; but, because of the difference between the sexes, varies more than $\Sigma$ does in males and females together. Relatively $\left[\mathrm{HCO}_{3}\right]$ varies most, but in actual milliequivalents variations of $[\mathrm{Na}]$ are almost twice as great. $\mathrm{Be}-$ yond the reciprocal relation between $\left[\mathrm{HCO}_{3}\right]$ and $[\mathrm{Cl}]$ in the 2 sexes, no significant correlation can be found between any 2 functions in either or both sexes. Even $\left[\mathrm{HCO}_{3}\right]$ and $[\mathrm{Cl}]$ bear no significant relation to one another in either males or females. The cause of the variations of $\Delta$ is, therefore, not clear from these data. The mean value of $\Delta$ in these normal subjects is about $5 \mathrm{meq}$. per liter, with all but 2 of the observations falling between 0 and 8.5. In normal persons under standard postabsorptive conditions, therefore, [Na] can be predicted from $\Sigma$ with an error that seldom exceeds 5 meq. per liter.
In pathological conditions this prediction is far less accurate. In 170 observations $\Delta$ exceeded 11 meq., its maximum value in normal subjects, 97 times. In 47 instances, or 28 per cent of the observations in disease, $\Delta$ exceeded 16 meq. per liter. These figures have no statistical significance since the data were obtained from patients selected, in the main, because some abnormality of serum electrolytes was suspected. They will serve the present purpose, however, because it is in just such cases that knowledge of $[\mathrm{Na}]$ is desirable. If it is assumed that the mean value of $[\mathrm{Na}]$ is $\mathbf{z}$ +5 meq., the concentration of $[\mathrm{Na}]$ would have been underestimated by more than 10 meq. in 28 per cent of the pathological subjects of this series.

\section{DISCUSSION}

It remains to examine the causes of large values of $\Delta$ and to learn whether their presence and magnitude could be inferred from clinical phenomena. The subject can be approached best through an analysis of the separate categories of disease. Although the patients with Addison's disease were studied under a great variety of conditions, as is evident from the wide variations of $[\mathrm{Na}],\left[\mathrm{HCO}_{3}\right]$ and $[\mathrm{Cl}], \Delta$ exceeded 11 meq. in 9 of the 37 observations and was slightly greater than 16 meq. once. In this disorder, therefore, $\mathbf{\Sigma}$ gives a reliable estimate of $[\mathrm{Na}]$. Reductions of either $\left[\mathrm{HCO}_{3}\right]$ or [Cl] are referable almost entirely to depletion of [Na]. Only in the most critical states is there any appreciable accumulation in the serum of inorganic phosphate or other anions. The one high figure for $\Delta, 18.2$ meq., in this series was found in a young adult male with implants of pellets of desoxycorticosterone. The observation was made immediately after admission. The patient had suffered from diarrhea and vomiting, he was in a state of collapse, and had been anuric for 24 hours. In addition he was cyanotic and had physical signs and $\mathrm{x}$-ray evidence of bronchopneumonia and atelectasis, confirmed at a subsequent autopsy. $[\mathrm{Na}],[\mathrm{Cl}]$ and $\left[\mathrm{HCO}_{3}\right]$ were, respectively, 141.0, 104.7 and 18.1 meq. per liter. Presumably anuria, circulatory collapse and the pulmonary disease prevented him from compensating more adequately for a starvation ketosis. Although the electrolyte pattern of his serum was rapidly restored to normal by the administration of fluids and measures di- 
rected to the support of his circulation, he died 4 days later.

The patients with pulmonary disease fall into 2 categories. In the first are subjects with tuberculosis who resemble patients with Addison's disease in their tendency to waste sodium in the urine (6). In only one of these did $\Delta$ exceed 11.0 meq. and then only by 0.2 meq. per liter. In the second category are patients with disorders of the respiratory system, such as asthma, which interfere with the discharge of $\mathrm{CO}_{2}$. This leads to elevation of $\left[\mathrm{HCO}_{3}\right]$ with a compensatory depression of [Cl]. In 2 cases of this type $\Delta$ exceeded 16 meq., being 20.1 in both. Both patients were intensely cyanotic; the blood nonprotein nitrogen of one was $49 \mathrm{mgm}$. per cent. Presumably lactic acid, and possibly other organic acids, were responsible for the high concentrations of organic acid. Such acids would ordinarily displace bicarbonate; but the respiratory disability in these cases prohibited compensation by this reaction. Instead bicarbonate was elevated, in 1 patient on 1 occasion to 56.0 meq. per liter.
The high frequency of excessive values of $\Delta$ in diabetic patients is to be expected. The acids are probably in most instances ketone bodies. It may be seen from Figure 1 that there is a fair inverse correlation between $\Delta$ and $\left[\mathrm{HCO}_{3}\right]$. When the quantity of acid in the circulation increases, 2 reactions are called into play: (1) the acids are excreted in the urine; (2) bicarbonate is displaced by the acid, while the $\mathrm{CO}_{2}$ thus released is excreted by the respiratory system. The relative amounts of sodium balanced by bicarbonate and by other acids, then, depend on the efficiency of these 2 processes. If the eliminative mechanisms are operating effectively, there should be some degree of inverse correlation between $\left[\mathrm{HCO}_{3}\right]$ and $\Delta$. Such a correlation is evident in the observations from diabetic patients.

In patients with renal disease, high values of $\Delta$ coincided regularly with gross nitrogen retention. Usually $\left[\mathrm{HCO}_{3}\right]$ was coincidently reduced. These bicarbonate deficits have been attributed to the accumulations in the serum of inorganic phosphate and sulfate, but these were not large enough to

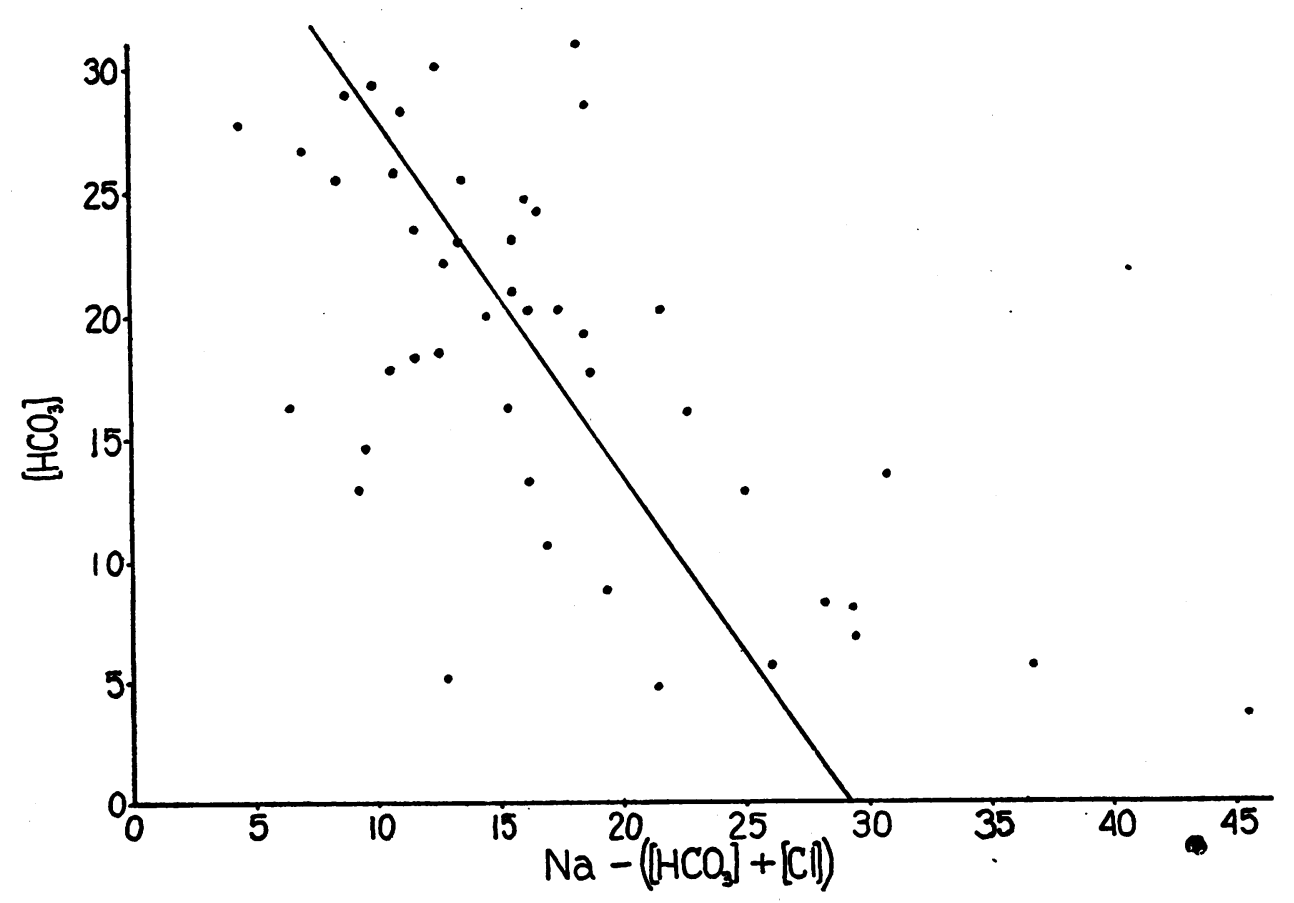

Fig. 1. The Relation of Bicarbonate to Undetermined Acids in Diabetic Patients Values are expressed in milliequivalents per liter. The diagonal line is defined by the equation, $29.31-0.685\left[\mathrm{HCO}_{8}\right]=\Delta$. 


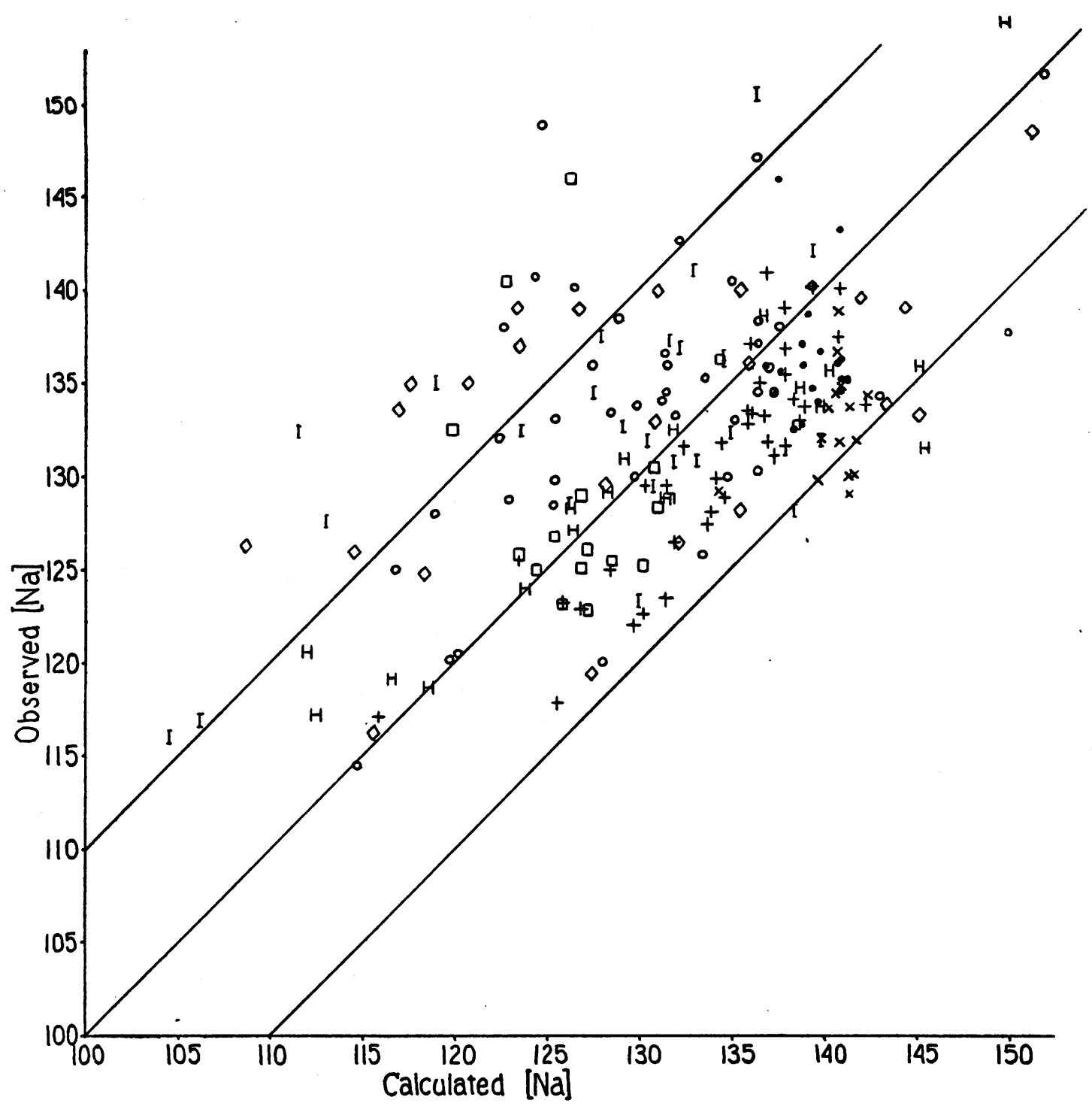

Fig. 2. Observed Values of Serum [Na] in Minliegutvalents per Liter Compared with Values Calculated BY THE EQUation,

$$
[\mathrm{Cl}]+\left[\mathrm{HCO}_{s}\right]+23.2-0.50\left[\mathrm{HCO}_{s}\right]=[\mathrm{Na}]
$$

The middle diagonal line represents perfect agreement; the 2 lines paralleling it delimit a zone of \pm 10 meq. per liter. The point $\mathrm{H}$ in the upper right-hand corner should actually be defined by observed $[\mathrm{Na}]=167.6$, calculated $[\mathrm{Na}]=164.4$. $\quad=$ normal male, $X=$ normal female, $+=$ Addison's disease, $\square=$ pulmonary disease, $O=$ diabetes mellitus, $\diamond=$ renal disease, $H=$ mercury poisoning, $I=$ miscellaneous disease.

explain both the bicarbonate deficits and the excesses of undetermined acids, which often amounted to 30 meq. per liter or more. Chloride was also reduced in many instances and sodium was seldom elevated. That the high $\Delta$ 's in renal disease were not referable to impaired renal function alone is suggested by comparison with mercury poisoning. In this condition; in spite of oliguria and high blood nonprotein nitrogen, $\Delta$ was usually quite moderate.

The miscellaneous series includes such heterogeneous cases that their analysis as a group cannot be profitable.

The mean line describing the relation of $\left[\mathrm{HCO}_{3}\right]$ to $\Delta$ in patients with diabetes is defined by the equation, $29.31-0.685\left[\mathrm{HCO}_{3}\right]=\Delta$, s.d. $= \pm$ 
6.61. From Figure 1 it is evident that the distribution of points about this line is somewhat asymmetrical. At high concentrations of $\left[\mathrm{HCO}_{3}\right] \Delta$ exceeds expectations. When the same line was tested on all observations it did not describe a general relation between abnormal accumulations of anions and $\left[\mathrm{HCO}_{3}\right]$. A similar line was, therefore, constructed from all observations. This line is defined by the equation, $23.2-0.50\left[\mathrm{HCO}_{3}\right]=$ $\Delta$, s.d. $= \pm 7.09$ meq. per liter. With the aid of this relation $\left[\mathrm{Na}\right.$ ] can be calculated from $\left[\mathrm{HCO}_{3}\right]$ and $[\mathrm{Cl}]$ by the equation, $[\mathrm{Cl}]+23.2+0.50$ $\left[\mathrm{HCO}_{3}\right]=[\mathrm{Na}]$, within \pm 10 meq. per liter in 86 per cent and within $\pm 15 \mathrm{meq}$. in 95 per cent of all observations. The relation between observed and calculated [Na] is shown in Figure 2. Although observed values of $\Delta$ are almost always positive, values estimated by the formula are both positive and negative. Some consistent trends are also noticeable. For example, calculated values of [Na] in normal subjects are, with 2 exceptions, greater than observed values. The 2 exceptions are in males. The difference is greater in females than in males. It may be that the line describing the relation of $\Delta$ to $\left[\mathrm{HCO}_{3}\right]$ is distorted by certain characteristics of one or more pathological groups or that this relationship is actually curvilinear.

Data on the subjects in which the calculated and observed values of [ $\mathrm{Na}$ ] differed from one another by more than 10 meq. per liter are presented in Table II. On 2 occasions in 1 female differences of -12.4 and -11.4 meq. were observed, on 3 other occasions the differences in the same subject were $-9.9,-9.9$., and -9.7 meq. per liter (the difference is given the negative sign when the calculated value is greater than the observed value). The observed $\Delta$ in the same sera varied from -1.3 to 3.6. Another of the normal women had a difference of -11.6 meq. with an observed $\Delta$ of 0.4 meq. per liter. These large negative differences were associated with high normal values of [Cl] (106.0 to $106.8 \mathrm{meq}$. per liter). One other normal female with a [Cl] of 106.8 meq. 'per liter had a difference of -8.6 meq. Among the women there is a tendency, not apparent in the men, for the negative error to vary with [Cl], which is consistently greater in females than in males. In the pathological series, calculated $[\mathrm{Na}]$ exceeded observed [Na] by more than 10 meq. per liter 4
TABLE II

Observations in which observed [Na] differed from calculated [Na] by more than 10 meq. per liter

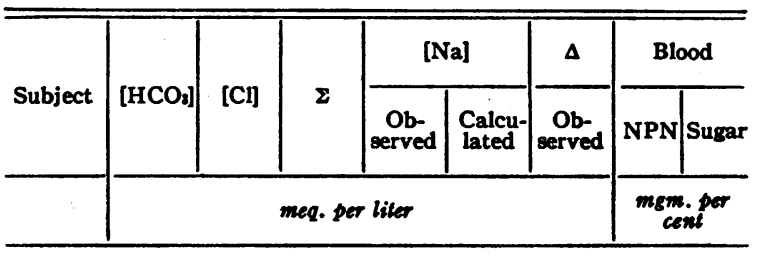

Normal females

\begin{tabular}{|c|c|c|c|c|c|c|c|}
\hline $\begin{array}{l}\mathrm{PMH} \\
\mathrm{RC}\end{array}$ & $\begin{array}{l}24.3 \\
24.4 \\
24.1\end{array}$ & $\begin{array}{l}106.0 \\
106.0 \\
106.4\end{array}$ & $\begin{array}{l}130.3 \\
130.4 \\
130.5\end{array}$ & $\begin{array}{l}129.0 \\
130.0 \\
130.1\end{array}$ & $\begin{array}{l}141.4 \\
141.4 \\
141.3\end{array}$ & $\begin{array}{r}-1.3 \\
-0.4 \\
0.4\end{array}$ & \\
\hline \multicolumn{8}{|c|}{ Pulmonary disease } \\
\hline $\begin{array}{l}\text { B84061 } \\
\text { A36064 }\end{array}$ & $\begin{array}{l}41.6 \\
56.0 \\
31.5\end{array}$ & $\begin{array}{l}78.8 \\
75.1 \\
80.9\end{array}$ & $\begin{array}{l}120.4 \\
131.1 \\
112.4\end{array}$ & $\begin{array}{l}140.5 \\
146.0 \\
132.5\end{array}$ & $\begin{array}{l}122.8 \\
126.3 \\
119.8\end{array}$ & $\begin{array}{l}20.1 \\
14.9 \\
20.1\end{array}$ & $\begin{array}{l}49 \\
21\end{array}$ \\
\hline
\end{tabular}

Diabetes mellitus

\begin{tabular}{l|r|r|r|r|r|r|r|r}
\hline 60404 & 5.7 & 98.2 & 103.9 & 140.7 & 124.3 & 36.8 & 33 & 588 \\
90339 & 17.8 & 118.0 & 135.8 & 137.6 & 150.1 & 1.8 & 37 & 224 \\
42994 & 3.6 & 99.8 & 103.4 & 148.9 & 124.8 & 45.5 & 42 & 588 \\
B47553 & 17.7 & 101.6 & 119.3 & 138.0 & 122.7 & 18.7 & & 61 \\
B31839 & 13.7 & 96.5 & 110.2 & 141.0 & 126.6 & 30.8 & 159 & \\
\hline
\end{tabular}

Renal disease

\begin{tabular}{|c|c|c|c|c|c|c|c|}
\hline $\begin{array}{l}\text { A8132 } \\
\text { B86920 }\end{array}$ & $\begin{array}{l}20.7 \\
20.0 \\
10.9 \\
13.3 \\
13.3 \\
12.7 \\
11.7 \\
14.2 \\
13.5\end{array}$ & \begin{tabular}{|r|}
111.5 \\
81.3 \\
98.1 \\
93.5 \\
90.9 \\
94.0 \\
88.6 \\
86.7 \\
79.7
\end{tabular} & \begin{tabular}{|r|}
132.2 \\
101.3 \\
109.0 \\
106.8 \\
104.2 \\
106.7 \\
100.3 \\
100.9 \\
93.2
\end{tabular} & \begin{tabular}{|l|}
133.2 \\
126.0 \\
139.0 \\
139.0 \\
135.0 \\
137.0 \\
135.0 \\
133.5 \\
126.3
\end{tabular} & \begin{tabular}{|l|}
145.1 \\
114.5 \\
126.8 \\
123.4 \\
120.8 \\
123.6 \\
117.7 \\
117.0 \\
108.7
\end{tabular} & $\begin{array}{r}1.0 \\
24.7 \\
30.0 \\
32.2 \\
30.8 \\
30.3 \\
34.7 \\
32.6 \\
33.1\end{array}$ & $\begin{array}{r}59 \\
111 \\
168 \\
232 \\
266 \\
278 \\
269 \\
158 \\
166\end{array}$ \\
\hline
\end{tabular}

Mercury poisoning

\begin{tabular}{|c|c|c|c|c|c|c|c|}
\hline 70280 & $\begin{array}{l}18.5 \\
16.4\end{array}$ & $\begin{array}{l}113.0 \\
113.8\end{array}$ & $\begin{array}{l}131.5 \\
130.2\end{array}$ & $\begin{array}{l}131.5 \\
135.9\end{array}$ & \begin{tabular}{|l|}
145.5 \\
145.2
\end{tabular} & $\begin{array}{l}0 \\
5.7\end{array}$ & $\begin{array}{l}47 \\
54\end{array}$ \\
\hline \multicolumn{8}{|c|}{ Miscellaneous diseases } \\
\hline $\begin{array}{l}\text { A39880 } \\
78642 \\
\text { B86345 } \\
\text { A60444 }\end{array}$ & $\begin{array}{l}29.0 \\
40.9 \\
35.8 \\
20.8 \\
27.3\end{array}$ & $\begin{array}{l}81.3 \\
67.8 \\
71.9 \\
70.8 \\
99.5\end{array}$ & $\begin{array}{r}110.3 \\
108.7 \\
107.7 \\
91.6 \\
126.8\end{array}$ & \begin{tabular}{|l|}
135.0 \\
132.4 \\
127.5 \\
116.0 \\
150.5 \\
\end{tabular} & \begin{tabular}{|l|}
119.0 \\
111.5 \\
113.0 \\
104.4 \\
136.4
\end{tabular} & $\begin{array}{l}24.7 \\
23.7 \\
19.8 \\
24.4 \\
23.7\end{array}$ & $\begin{array}{r}27 \\
49 \\
194 \\
33\end{array}$ \\
\hline
\end{tabular}

times, always when [Cl] was greater than 110.0 meq. per liter. In only 1 observation out of 7 in which [Cl] exceeded 110.0 meq. per liter was observed [Na] greater than calculated [Na]. In this case, a diabetic in acidosis, when [Cl] was 122.2 meq. per liter, the difference was $13.3 \mathrm{meq}$. (observed $\Delta 1.3$ meq.). The observed [Na] on 
this occasion was 151.6 meq. per liter. In all other instances high $[\mathrm{Cl}]$ was associated with a normal $[\mathrm{Na}]$. It therefore appears that when $[\mathrm{Cl}]$ exceeds 110.0 meq. per liter the prediction equation usually overestimates $[\mathrm{Na}]$. If $\left[\mathrm{HCO}_{3}\right]$ is depressed by hyperchloremia there is no reason why $\Delta$ should be increased. Since the prediction equation is based on the assumption that any depression of $\left[\mathrm{HCO}_{3}\right]$ is referable to an increase in the serum of the concentration of anions other than [Cl], it follows that when $\left[\mathrm{HCO}_{3}\right]$ is depressed by $[\mathrm{Cl}]$ itself the equation will yield too high a value for $[\mathrm{Na}]$.

Calculated $[\mathrm{Na}]$ was lower than observed [Na] by more than 10 meq. per liter in 2 patients with pulmonary disease. Both had asthma, emphysema, and heart failure. Among the nephritics also, only those with heart failure and pulmonary congestion had large positive differences. This affords an explanation for the absence of such errors in the patients with mercury poisoning, who had no respiratory impairment. Observed $[\mathrm{Na}]$ exceeded calculated [Na] by more than 10 meq. in 4 patients with miscellaneous diseases. The first of these, who had encephalitis, at the time of the examination was stuporous, cyanotic, and breathing stertorously. His $\left[\mathrm{HCO}_{3}\right]$ was high, $[\mathrm{Cl}]$ greatly reduced, with $[\mathrm{Na}]$ normal. It may be inferred that he had a primary $\mathrm{CO}_{2}$ excess. The second case, A78642, besides diabetic acidosis had pyloric obstruction. He was extremely dehydrated and in a state of circulatory collapse. B86345, with a broken neck, had retention of urine and circulatory failure. He was deeply cyanotic, his lungs full of bubbling rales. In all these cases, therefore, a large positive difference was associated with impairment of the respiratory system which interfered with the elimination of $\mathrm{CO}_{2}$. Invariably [Cl] was reduced; presumably, it was taking over the function of $\left[\mathrm{HCO}_{3}\right]$ in making room for the extra load of anions. The latter was also often diminished, especially in the patients with renal disease, but less than it would have been had the respiratory exchange been unimpaired. Consequently the usual inverse proportionality between $\left[\mathrm{HCO}_{3}\right]$ and $\Delta$ was not maintained. Respiratory insufficiency in these cases was not absolute, but relative.

The last patient, A60444, was in an active stage of familial periodic palsy with a serum potassium of 1.7 meq. per liter. Whether this interfered with his respiratory exchange, it is impossible to say because the analysis was made for routine diagnostic purposes and associated disturbances of his vital signs were not noted.

Of the diabetic cases, 90339 with high [Cl] has already been mentioned among those who had negative differences with hyperchloremia. In the remaining 4 observed [Na] exceeded calculated [Na] by 14 to 24 meq. per liter. Two of these patients, 60404 and 42994, had extreme acidosis and dehydration. It may be that the respiratory system had to assume more than its usual share of the burden because the kidneys were unable under these circumstances to work efficiently. On the other hand, it may be, as was suggested above, that the relation of $\left[\mathrm{HCO}_{3}\right]$ to $\Delta$ is actually curvilinear. At normal $\left[\mathrm{HCO}_{3}\right]$ the prediction equation seemed to exaggerate $[\mathrm{Na}]$; at extremely low $\left[\mathrm{HCO}_{3}\right]$ it may yield values that are too low. Errors of this nature and magnitude in extreme diabetic acidosis would not, however, lead to improper impressions or therapy. The other 2 patients had frank evidences of heart failure; in B31839 this was complicated by bronchiectasis, asthma, and emphysema.

It appears, therefore, to be possible to estimate serum $[\mathrm{Na}]$ within \pm 10 meq. per liter from $\left[\mathrm{HCO}_{3}\right]+[\mathrm{Cl}]$ with the aid of clinical observation. In such estimations account must be taken of the fact that as anions other than $\left[\mathrm{HCO}_{3}\right]$ and [Cl] accumulate in the serum $\Delta$ increases in inverse proportion to the depression of $\left[\mathrm{HCO}_{3}\right]$. A prediction formula has been devised by which these increases of $\Delta$ may be calculated from $\left[\mathrm{HCO}_{3}\right]$. In at least 2 conditions this formula fails. If $\left[\mathrm{HCO}_{3}\right]$ is displaced by $[\mathrm{Cl}]$ it yields excessively high calculated values for $[\mathrm{Na}]$; if the respiratory elimination of $\mathrm{CO}_{2}$ is impaired it yields erroneously low values.

There can be no doubt that direct measurement of [Na] will give more precise information; but no other combination of any 2 of the 3 variables, $[\mathrm{Na}],\left[\mathrm{HCO}_{3}\right]$ and $[\mathrm{Cl}]$, will be as serviceable as $\left[\mathrm{HCO}_{3}\right]+[\mathrm{Cl}]$. The combination of $[\mathrm{Na}]$ and $\left[\mathrm{HCO}_{3}\right]$ would obviously be most inadequate because the difference between these 2 would include the largest anion fraction, $[\mathrm{Cl}]$, as well as $\Delta$. In diabetic acidosis and other conditions, such as exercise or anoxemia, in which $\Delta$ is composed of combustible organic anions, measurements of $[\mathrm{Na}]$ and $[\mathrm{Cl}]$ would give useful information. In these 
conditions it could be assumed that the whole difference, $[\mathrm{Na}]-[\mathrm{Cl}]$, was potentially bicarbonate, since the sodium liberated by the combustion of these foreign acids would form bicarbonate with $\mathrm{CO}_{2}$. In renal insufficiency, however, when phosphate and sulfate accumulate in the serum, [Na] - [Cl] would have an altogether different significance and would give imperfect information.

\section{SUMMARY}

A prediction formula has been devised by which the concentration of sodium in blood serum may be estimated within \pm 10 meq. per liter from the concentrations of $\mathrm{CO}_{2}$ and chloride. Two conditions have been found in which this formula is inapplicable. In hyperchloremia it yields erroneously high values; when the respiratory elimination of $\mathrm{CO}_{2}$ is impaired it yields erroneously low values. Since these sources of error are readily detectable they do not detract greatly from the value of the formula.

\section{BIBLIOGRAPHY}

1. Peters, J. P., and Van Slyke, D. D., Quantitative Cliniical Chemistry. Methods. Williams and Wilkins Co., Baltimore, 1931.

2. Hald, P. M., Notes on the determination and distribution of sodium and potassium in cells and serum of normal human blood. J. Biol. Chem., 1946, 163, 429.

3. Hald, P. M., The flame photometer for the measurement of sodium and potassium in biological materials. J. Biol. Chem., 1947, 167, 499.

4. Hastings, A. B., Sendroy, J., Jr., and Van Slyke, D. D., Studies of gas and electrolyte equilibria in blood. XII. The value of $\mathrm{pK}$ in the Henderson-Hasselbalch equation for blood serum. J. Biol. Chem., 1928, 79, 183.

5. Peters, J. P., and Van Slyke, D. D., Quantitative Clinical Chemistry. Interpretations. Williams and Wilkins Co., Baltimore, 1931.

6. Winkler, A. W., and Crankshaw, O. F., Chloride depletion in conditions other than Addison's disease. J. Clin. Invest., 1938, 17, 1. 